\title{
1 European small portable rainfall simulators: A comparison of
}

\section{2 rainfall characteristics}

3 T. Iserloh $^{\mathrm{a}^{*}}$, J.B. Ries ${ }^{\mathrm{a}}$, J. Arnáez ${ }^{\mathrm{b}}$, C. Boix-Fayos ${ }^{\mathrm{c}}$, V. Butzen ${ }^{\mathrm{a}}$, A. Cerdà ${ }^{\mathrm{d}}$, M.T. Echeverría ${ }^{\mathrm{e}}$, 4 J. Fernández-Gálvez ${ }^{f}$, W. Fister ${ }^{g}$, C. Geißler ${ }^{h}$, J.A. Gómez', H. Gómez-Macpherson', N.J. 5 Kuhn $^{g}$, R. Lázaro', F.J. León ${ }^{\mathrm{e}}$, M. Martínez-Mena ${ }^{\mathrm{c}}$, J.F. Martínez-Murillo ${ }^{\mathrm{k}}$, M. Marzen ${ }^{\mathrm{a}}$, M.D. 6 Mingorance $^{f}$, L. Ortigosa ${ }^{b}$, P. Peters', D. Regüés ${ }^{m}$, J.D. Ruiz-Sinoga ${ }^{k}$, T. Scholten ${ }^{h}, M$.

a Physical Geography, Trier University, 54286 Trier, Germany

${ }^{b}$ Physical Geography, University of La Rioja, 26004 Logroño, Spain

${ }^{c}$ Soil and Water Conservation Department (CEBAS-CSIC), 30100 Murcia, Spain

${ }^{d}$ Department of Geography, University of Valencia, 46010 Valencia, Spain

e Department of Geography and Spatial Management, University of Zaragoza, 50009 Zaragoza, Spain

${ }^{f}$ Andalusian Institute for Earth Sciences (UGR-CSIC), 18100 Granada, Spain

${ }^{g}$ Physical Geography and Environmental Change, University of Basel, 4056 Basel, Switzerland

${ }^{h}$ Physical Geography and Soil Science, Eberhard Karls University Tübingen, 72070 Tübingen, Germany

i Institute for Sustainable Agriculture (IAS-CSIC), Apartado 4084, 14080 Córdoba, Spain

${ }^{j}$ Arid Zones Experimental Station (EEZA-CSIC), 04120 Almería, Spain

${ }^{k}$ Department of Geography, University of Málaga, 29079 Málaga, Spain

'Land Degradation and Development, Wageningen University, 6700 Wageningen, the Netherlands

${ }^{m}$ Pyrenean Institute of Ecology (IPE-CSIC), 50059 Zaragoza, Spain

"Corresponding author: Tel.: +49-651-2013390, e-mail: iserloh@uni-trier.de, Fax: +49-651-2013976.

DOI: 10.1016/j.catena.2013.05.013

Abstract Small-scale portable rainfall simulators are an essential research tool for

investigating the process dynamics of soil erosion and surface hydrology. There is no standardisation of rainfall simulation and such rainfall simulators differ in design, rainfall intensities, rain spectra and research questions, which impede drawing a meaningful comparison between results. Nevertheless, these data become progressively important for soil erosion assessment and therefore, the basis for decision-makers in application-oriented erosion protection.

The artificially generated rainfall of the simulators used at the Universities Basel, La Rioja, was measured with the same methods (Laser Precipitation Monitor for drop spectra and rain collectors for spatial distribution). Data are very beneficial for improvements of simulators and comparison of simulators and results. Furthermore, they can be used for comparative studies, e.g. with measured natural rainfall spectra. A broad range of rainfall data was measured (e.g. intensity: $37-360 \mathrm{~mm} \mathrm{~h}^{-1}$; Christiansen Coefficient for spatial rainfall distribution: $61-98 \%$; median volumetric drop diameter: $0.375-6.5 \mathrm{~mm}$; mean kinetic 
energy expenditure: $25-1322 \mathrm{~J} \mathrm{~m}^{-2} \mathrm{~h}^{-1}$; mean kinetic energy per unit area and unit depth of rainfall: $0.77-50 \mathrm{~J} \mathrm{~m}^{-2} \mathrm{~mm}^{-1}$ ). Similarities among the simulators could be found e.g. concerning drop size distributions (maximum drop numbers are reached within the smallest drop classes $<1 \mathrm{~mm}$ ) and low fall velocities of bigger drops due to a general physical restriction. The comparison represents a good data-base for improvements and provides a consistent picture of the different parameters of the simulators that were tested.

\section{Keywords:}

Rainfall simulator comparison; Runoff; Drop size; Drop velocity; Kinetic energy; Spatial rainfall distribution; Water erosion

\section{Introduction}

Rainfall simulation has become an important method for assessing the subjects of soil erosion and soil hydrological processes. It is an essential tool for investigating the different erosion processes in situ and in the laboratory, particularly for quantifying rates of detachment and transportation of material (e.g. Cerdà, 1999). Its application allows a quick, specific and reproducible assessment of the meaning and impact of several factors, such as slope, soil type (infiltration, permeability), soil moisture, splash effect of raindrops (aggregate stability), surface structure, vegetation cover and vegetation structure (Bowyer-Bower and Burt, 1989; Schmidt, 1998). The possibility of high repetition rate offers a systematic approach to address the different factors that influence soil erosion even in remote areas and in regions where highly erosive rainfall events are rare or irregular. A compilation of different rainfall simulator systems is given by Meyer (1988) and Hudson (1995). Cerdà (1999) reports on the history of rainfall simulation over the past 62 years and lists 229 different simulators by author, year of construction, application by country, nozzle type, capillary material, drop diameter, precipitation intensity, plot size and research question.

The need to distinguish the different partial processes of runoff generation and erosion led to the development of rainfall simulations on small plots (Calvo et al., 1988). The advantages of 
small portable rainfall simulators are, among others, the low costs, the easy transport in inaccessible areas and the low water consumption. Small portable rainfall simulators also enable data to be obtained under controlled conditions and over relatively short time periods. They have been used worldwide by different research groups for many years. Since 1938 more than 100 rainfall simulators with plot dimensions $<5 \mathrm{~m}^{2}$ (most of them $<1 \mathrm{~m}^{2}$ ) were developed (e.g. Abudi et al., 2012; Adams et al., 1957; Alves Sobrinho et al., 2008; Battany and Grismer, 2000; Birt et al., 2007; Blanquies et al., 2003; Bork, 1981; Bryan, 1974; Calvo et al., 1988; Cerdà et al., 1997; Clarke and Walsh, 2007; Farres, 1987; Hudson, 1965; Humphry et al., 2002; Imeson, 1977; Kamphorst, 1987; Loch et al., 2001; Luk, 1985; Martínez-Mena et al., 2001a; Medalus, 1993; Nadal-Romero and Regüés, 2009; Neal, 1937; Norton, 1987; De Ploey, 1981; Poesen et al., 1990; Regmi and Thompson, 2000; Regüés and Gallart, 2004; Roth et al., 1985; Torri et al., 1999; Wilm, 1943). There is no standardisation of rainfall simulation and these rainfall simulators differ in design, rainfall intensities, spatial rainfall distribution, drop sizes and drop velocities, which impede drawing a meaningful comparison between results. Nevertheless, the data have become progressively important for soil erosion assessment and decision-making in application-oriented erosion protection. Therefore, the accurate knowledge of test conditions is a fundamental requirement and is essential to interpret, combine and classify results (Boulal et al., 2011; Clarke and Walsh, 2007; Lascelles et al., 2000; Ries et al., 2013).

A summary of major requirements for small portable rainfall simulators is given in Iserloh et al. (2012). The most substantial and critical properties of a simulated rainfall are the drop size distribution (DSD), the fall velocities of the drops and the spatial distribution of the rainfall on the plot-area. Since the 1970s, published studies have shown variations in these properties generated by respective simulators (e.g. Cerdà et al., 1997; Fister et al., 2011, 2012; Hall, 1970; Hassel and Richter, 1988; Humphry et al., 2002; Iserloh et al., 2012; Kincaid et al., 1996; King et al., 2010; Lascelles et al., 2000; Ries et al., 2009; Salles et al., 1999; Zhao et al., 1996). Many techniques were used to characterise simulated rainfall, such as the flour pellet method (Hudson, 1963; Laws and Parsons, 1943), laser particle measuring system (Salles and Poesen, 1999; Salles et al., 1999), plaster micro plot (Ries and Langer, 2001), indication paper (Brandt, 
1989; Cerdà et al., 1997; Salles et al., 1999; Wiesner, 1895), Joss-Waldvogel Disdrometer (Hassel and Richter, 1988; Joss and Waldvogel, 1967) and the oil method (Gunn and Kinzer, 1949) among others. It was shown that the results of the characterisation of simulated rainfall were extremely dependent on the particular method that was applied (Ries et al., 2009). Against this backdrop, a standardized method for verifying and calibrating the characteristics of simulated rainfall is paramount, and the Laser Precipitation Monitor (LPM) represents the most up-todate and accurate measurement technique for obtaining information on drop spectra and drop fall velocities (King et al., 2010; Ries et al., 2009), along with an optimal price-performance ratio. Quantity and spatial distribution of the simulated rain can be easily measured with raincollectors (covering the complete testplot) at low cost and good performance.

In this study, artificial rainfall generated by 13 rainfall simulators based in various European research institutions from Germany, the Netherlands, Spain and Switzerland was characterised using LPM and rain collectors in all simulations in order to ensure comparability of the results. The studied rainfall simulators represent most of the devices that have been used in Europe over the last decade and they present a wide range of designs, plot dimensions $\left(0.06 \mathrm{~m}^{2}\right.$ up to $\left.1 \mathrm{~m}^{2}\right)$, numbers and types of nozzles and rainfall intensities. The main research question to be answered is: What are the most important differences/similarities in the suite of simulated rainfall characteristics investigated?

\section{Material \& methods}

\subsection{Rainfall simulators}

The 13 small portable field rainfall simulators that were tested are shown in Fig. 1 and their main characteristics are listed in Table 1. The simulators are three new developed prototype nozzle-type simulators based at Tübingen (TU), Cordoba (CO) and Basel (BA) as well as two capillary-type simulators from Granada (GR) and Wageningen (WA). The eight other simulators are round plot nozzle-type simulators based at Almeria (AL), Malaga (MA), Murcia (MU), Trier (TR), Zaragoza-CSIC (ZAC), Valencia (VA), Zaragoza-University (ZAU) and La Rioja (LR), and their design follows Calvo et al. (1988) and Cerdà et al. (1997). This round plot 
124 type of rainfall simulator is the most common device used in semi-arid areas in Europe, 125 especially in Spain, and major differences typically occur in pumps, nozzles and applied 126 intensities. Duration of all simulators is adjustable, only the WA-simulator is limited to three 127 min, due to its compact design.

128

129 Table 1

130 The main characteristics of small scale portable rainfall simulators tested (ranked in order of plot size).

\begin{tabular}{|c|c|c|c|c|c|c|}
\hline ID & $\begin{array}{r}\text { Plot size } \\
{\left[\mathrm{m}^{2}\right]}\end{array}$ & Plot design & $\begin{array}{r}\text { Falling } \\
\text { height }[\mathrm{m}]\end{array}$ & $\begin{array}{r}\text { Nozzle / Drop } \\
\text { formers }\end{array}$ & Water source & Details \\
\hline TU & 1.000 & $\begin{array}{l}1 \mathrm{~m} \times 1 \mathrm{~m}, \\
\text { rectangular }\end{array}$ & 3.43 & Lechler 460.788 .30 & $\begin{array}{r}\text { Electric pressure pump (driven by } \\
\text { power generator) }\end{array}$ & Iserloh et al. (2013) \\
\hline $\mathrm{CO}$ & 0.700 & $\begin{array}{r}1 \mathrm{~m} \times 0.7 \mathrm{~m}, \\
\text { rectangular }\end{array}$ & 2.30 & Veejet 80.150 & $\begin{array}{r}\text { Electric pressure pump (driven by } \\
\text { power generator) }\end{array}$ & Alves Sobrinho et al. (2008) \\
\hline BA & 0.700 & $\begin{array}{l}1.34 \mathrm{~m} \times 1.0 \mathrm{~m} \mathrm{x} \\
0.3 \mathrm{~m} \text {, trapezoid }\end{array}$ & 1.10 & $\begin{array}{r}\text { Spraying Systems } \\
3 / 8 \mathrm{HH} 20 \mathrm{~W} \mathrm{SQ}\end{array}$ & $\begin{array}{r}\text { Electric pressure pump (driven by } \\
\text { power generator) }\end{array}$ & $\begin{array}{r}\text { Hikel et al. (2013); Iserloh et al. } \\
\text { (2013) }\end{array}$ \\
\hline GR & 0.250 & $\begin{array}{r}0.5 \mathrm{~m} \times 0.5 \mathrm{~m}, \\
\text { rectangular }\end{array}$ & 1.50 & 4900 capillaries per $\mathrm{m}^{2}$ & $\begin{array}{l}\text { Electric peristaltic pump (driven by } \\
\text { power generator)+ Mariotte's bottle }\end{array}$ & Fernández-Gálvez et al. (2008) \\
\hline$A L$ & 0.283 & round & 2.00 & Hardi 4680-10E & $\begin{array}{r}\text { Gasoline engine driven pressure } \\
\text { pump }\end{array}$ & e.g. Li et al. (2011) \\
\hline MA & 0.283 & round & 2.00 & Hardi $1553-20$ & $\begin{array}{r}\text { Electric pressure pump (driven by } \\
\text { power generator) }\end{array}$ & $\begin{array}{r}\text { e.g. Martínez-Murillo and Ruiz- } \\
\text { Sinoga (2007) }\end{array}$ \\
\hline MU & 0.283 & round & 2.00 & Lechler 402.608 .30 & $\begin{array}{r}\text { Gasoline engine driven pressure } \\
\text { pump }\end{array}$ & Martínez-Mena et al. (2001b) \\
\hline TR & 0.283 & round & 2.00 & Lechler 460.608 .30 & $\begin{array}{l}\text { Gasoline engine driven pump or } \\
\text { electrical pump (driven by battery) }\end{array}$ & Iserloh et al. $(2012,2013)$ \\
\hline ZAC & 0.283 & round & 2.22 & Lechler 460.688 .30 & $\begin{array}{r}\text { Gasoline engine driven pressure } \\
\text { pump }\end{array}$ & $\begin{array}{r}\text { Nadal-Romero and Regüés } \\
\text { (2009); Nadal-Romero et al. } \\
\text { (2011) }\end{array}$ \\
\hline VA & 0.246 & round & 2.00 & Hardi 155312 & $\begin{array}{l}\text { Gasoline engine driven pump or } \\
\text { electrical pump (driven by battery) }\end{array}$ & $\begin{array}{r}\text { Cerdà et al. (1997); Iserloh et al. } \\
\text { (2013) }\end{array}$ \\
\hline ZAU & 0.212 & round & 2.18 & Lechler 460.688 .30 & $\begin{array}{r}\text { Gasoline engine driven pressure } \\
\text { pump }\end{array}$ & $\begin{array}{r}\text { Iserloh et al. (2013); León et al. } \\
\text { (2013) }\end{array}$ \\
\hline LR & 0.160 & round & 2.50 & Lechler 460.608 .17 & $\begin{array}{r}\text { Gasoline engine driven pressure } \\
\text { pump }\end{array}$ & Arnaez et al. (2007) \\
\hline WA & 0.159 & $\begin{array}{r}0.24 \mathrm{~m} \times 0.24 \mathrm{~m}, \\
\text { rectangular }\end{array}$ & 0.40 & 49 capillaries & Cylindrical reservoir over capillaries & Iserloh et al. (2013); Kamphorst \\
\hline
\end{tabular}

131

$132 \quad 2.2$ Methods for evaluating rainfall characteristics

133 a) Drop size distribution and drop fall velocities

134 The Thies Laser Precipitation Monitor (LPM) was used for analysing the DSD and drop fall

135 velocities. LPM measures the amount and intensity of rainfall and determines rain-drop size

136 and velocity as the drops fall through a laser beam (area of $46 \mathrm{~cm}^{2}(23 \times 2 \mathrm{~cm})$ ). It registers

137 individual drops with diameters ranging from $0.16 \mathrm{~mm}$ to $8 \mathrm{~mm}$, and fall velocities ranging

138 from $0.2 \mathrm{~m} \mathrm{~s}^{-1}$ to $20 \mathrm{~m} \mathrm{~s}^{-1}$, up to a maximum intensity of $250 \mathrm{~mm} \mathrm{~h}^{-1}$ (Thies, 2004). A more

139 detailed description of the LPM is given in Angulo-Martínez et al. (2012), Fister et al. (2012), 
140 King et al. (2010) and Scholten et al. (2011). Because the LPM records only drop size and drop

141 velocity classes, we used the mean value of each class to calculate kinetic energy,

142 momentum and median volumetric drop diameter $\left(d_{50}\right)$.

\section{3 b) Spatial rainfall distribution}

144 In order to generate quantitative information about the homogeneity and the reproducibility of

145 rainfall, small rainfall collectors were used to measure the spatial rainfall distribution. The

146 entire test plot was covered by collectors: square ones $\left(56 \mathrm{~cm}^{2}\right.$; in case of Basel: $\left.100 \mathrm{~cm}^{2}\right)$

147 for square plots and round collectors $\left(20 \mathrm{~cm}^{2}\right)$ for round plots (Fig 2).

148

\section{$149 \quad 2.3$ Test procedure}

150 A standardized test procedure was developed and performed with the simulators.

151 Prior to each test sequence, rainfall intensity was calibrated using the method generally

152 applied by each group to maintain the customary rainfall conditions of their experimental

153 work. TR and VA used a calibration plate covering the whole plot, TU used the LPM

154 technique, and the remaining groups used rain collectors.

155 Water discharge of nozzles was determined using the volumetric method.

156 In order to analyse drop spectra with the LPM, five representative positions within the total 157 plot area were chosen (Fig. 2). At each position, five replications at one minute measurement

158 intervals were performed (except the WA-simulator whose design allows only a maximum

159 duration of three minutes). Due to the bodywork of the LPM, the measurement height is

$16015 \mathrm{~cm}$ above ground.

161 Exposure time of collectors to rainfall during each replicate experiment was five min, and a 162 total of three repetitions were undertaken. The individual collectors were weighed to 163 determine spatial variations in the mass, and hence the volume of water at each location 164 within the plot. The results were calculated as equivalent intensity values $\left(\mathrm{mm} \mathrm{h}^{-1}\right)$ and 165 spatially displayed. The measurement of rainfall distribution of the WA-simulator was not 166 possible due to the compact construction of the simulator. 


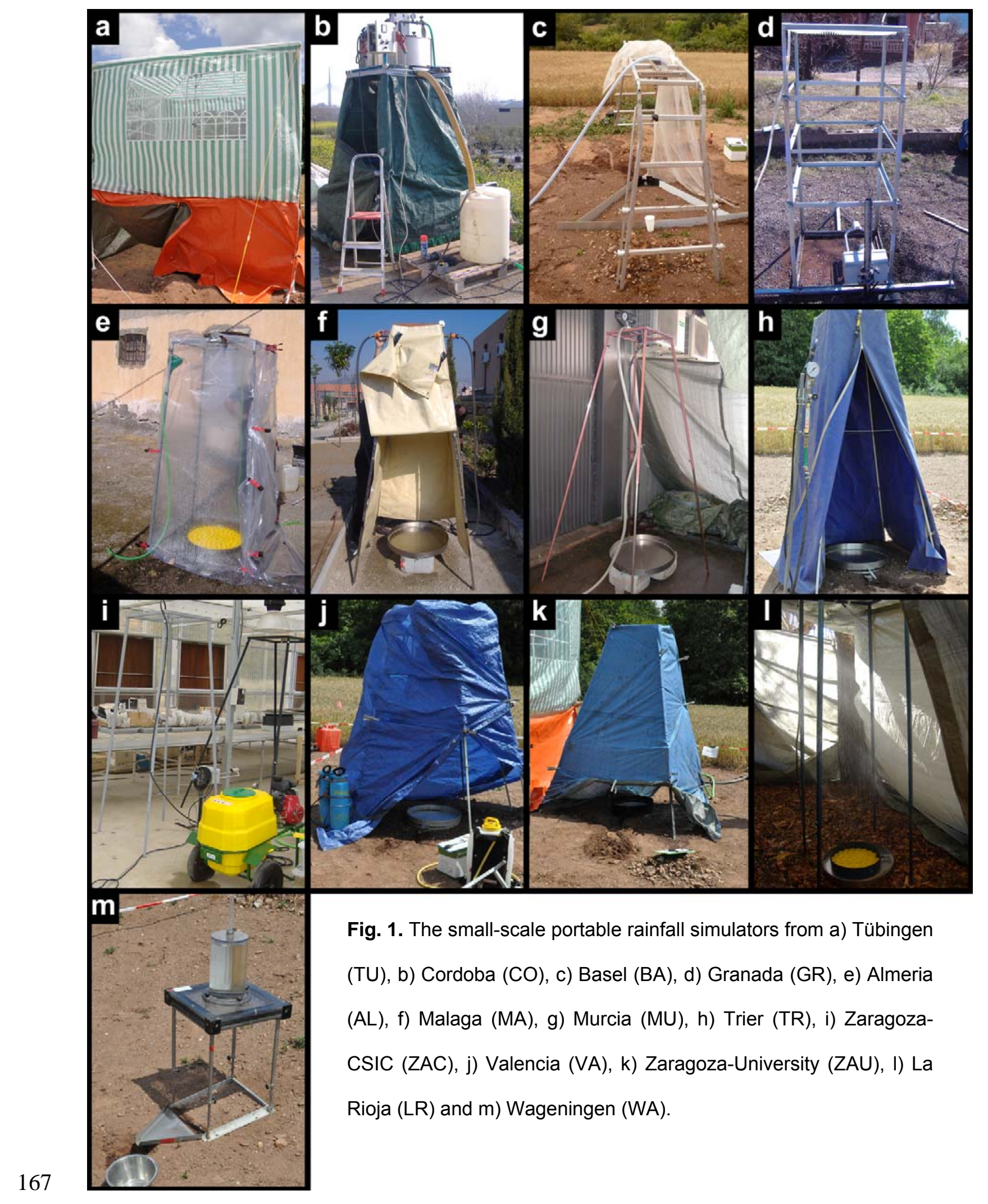




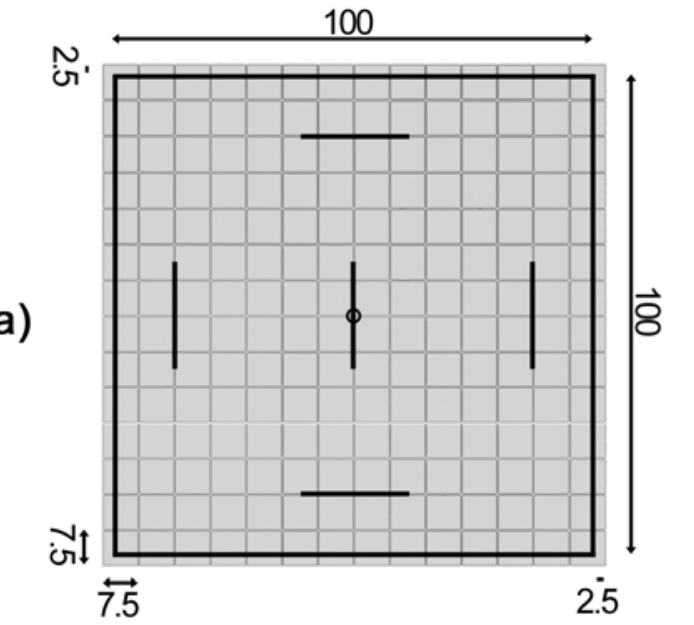

130

c)

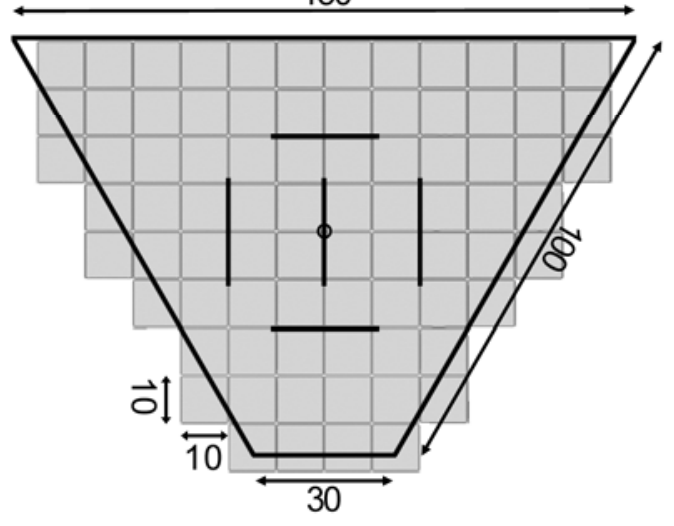

e)
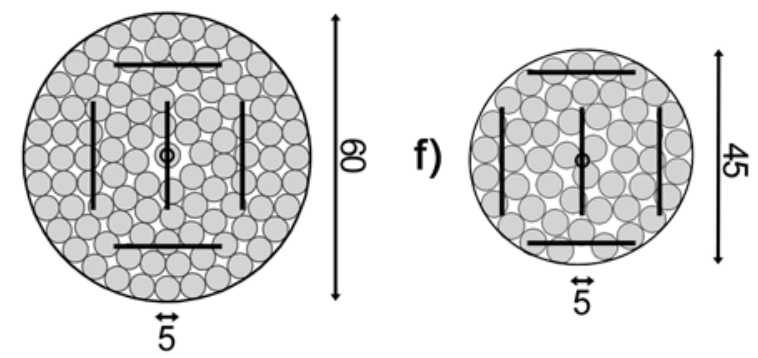

b)

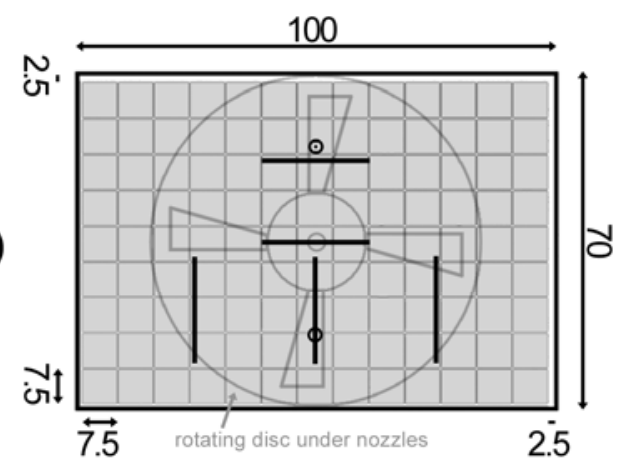

d)
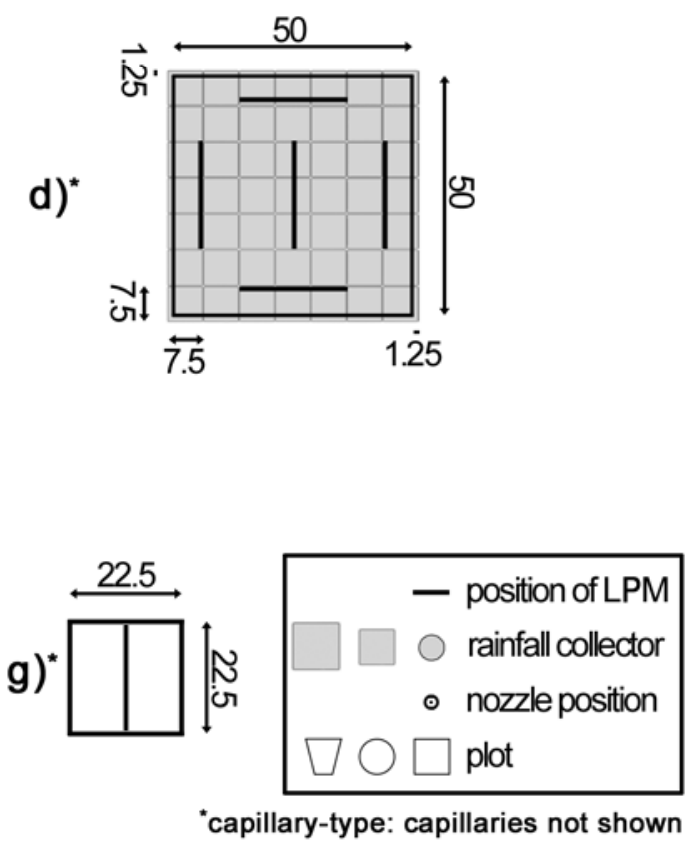

Fig. 2. Test set-up: a) Tübingen (TU), b) Cordoba (CO), c) Basel (BA), d) Granada (GR), e) Almeria (AL), Malaga (MA), Murcia (MU), Trier (TR), Zaragoza-CSIC (ZAC), Valencia (VA) and ZaragozaUniversity (ZAU), f) La Rioja (LR) and g) Wageningen (WA). LPM = Laser Precipitation Monitor.

\subsection{Further calculations}

\section{a) Rainfall kinetic energy and momentum}

175 Rainfall kinetic energy was calculated using equations from Fornis et al. (2005). These equations were provided relating to the development of the Disdrometer RD-80 (Disdromet Ltd, Basel, Switzerland, 2001) and are optimally applicable for the LPM by Thies. In order to 
178 compute the rate of kinetic energy expenditure $\left(K E_{R}, \mathrm{~J} \mathrm{~m}^{-2} \mathrm{~h}^{-1}\right)$ for every 1-min period, the

179 following equation was used:

$180 \quad K E_{R}=\left(\frac{\pi}{12}\right)\left(\frac{1}{10^{6}}\right)\left(\frac{3600}{t}\right)\left(\frac{1}{A}\right) \sum_{i=1}^{20} n_{i} D_{i}^{3}\left(v_{D_{i}}\right)^{2}$

181 where $A=0.0046 \mathrm{~m}^{2}$ is the sampling area of the LPM, $n_{i}$ the number of drops of diameter $D_{i} ; v_{D_{i}}$ the measured fall velocity of drop with diameter $D_{i}$ and $t=60 \mathrm{~s}$.

183 The kinetic energy per unit area and unit depth of rainfall, $K E\left(\mathrm{~J} \mathrm{~m}^{-2} \mathrm{~mm}^{-1}\right)$ was calculated 184 using equation (2):

$185 K E=\left(\frac{K E_{R}}{I}\right)$

186 where $/$ is the rainfall intensity $\left(\mathrm{mm} \mathrm{h}^{-1}\right)$ measured with the LPM.

187 Brodie and Rosewell (2007) concluded that key processes of particle wash-off due to rainfall 188 are slightly more dependent on momentum $(M)$ than on $K E$, therefore momentum was 189 calculated following their approach. The calculations in equation (3) were made on the basis 190 that the momentum $M\left(\mathrm{~kg} \mathrm{~m} \mathrm{~s}^{-1}\right)$ of an individual raindrop of diameter $D_{n}$ is:

$191 M_{n}=10^{-3} \times m_{n} v_{F n}$

192 where $m_{n}$ is mass $(\mathrm{g})$ of $D_{n}$ raindrop, $v_{F n}$ is terminal fall velocity $\left(\mathrm{m} \mathrm{s}^{-1}\right)$ of $D_{n}$ raindrop in still 193 air.

$194 v_{F n}$ is measured by the LPM, the mass, $m_{n}$, must be calculated (Eq. 4), and the drop volume

$195 V_{n}\left(\mathrm{~mm}^{3}\right)$ is to be determined (Eq. 5), while it is calculated from the measured drop 196 diameters $D_{n}$.

$197 m_{n}=10^{-3} V_{n}$

$198 \quad V_{n}=\frac{\pi}{6} D_{n}^{3}$ 


\section{b) Median volumetric drop diameter}

203 The median volumetric drop diameter $\left(d_{50}\right)$ was calculated from the percentage total mass of 204 raindrops in each size class according to Hudson (1995) and Clarke and Walsh (2007). For the 205 calculation, the volumes of spherical drops have been assumed.

In order to compare results between different simulators, the mean Christiansen Uniformity (CU) coefficient (Christiansen, 1942) was calculated using equation (6).

210 where $\sum_{i=1}^{n}\left|x_{i}-\bar{x}\right|$ is the sum of the absolute deviations from mean water amount of all rain 211 collectors [ml], $x_{i}$ is individual water amount per rain collector [ml], $\bar{x}$ is the arithmetic mean 212 of applied water amount per rain collector [ml] and $\mathrm{n}$ is the total number of rain collectors.

213 For the characterisation of spatial rainfall variability, the deviation from the mean was calculated for each collector based on the three replicate tests performed for each rainfall simulator. The deviation was then normalised by the mean rainfall intensity of the respective cell to compute a quantitative measure for the spatial reproducibility of simulated rainfall.

\section{Results and discussion}

219 The main rainfall characteristics for each simulator are presented in Table 2. The rainfall simulators of the participating institutes produced a broad range of intensities, from $37 \mathrm{~mm} \mathrm{~h}^{-}$

$221{ }^{1}$ (MA) to $360 \mathrm{~mm} \mathrm{~h}^{-1}$ (WA). Total water consumption per min depends on the applied 222 intensity, the plot size and the size of nozzle used (e.g. due to different spray angles and 223 applied water pressure). The results ranged from $0.49 \mathrm{~L} \mathrm{~min}^{-1}$ for $A L$ and VA, to $3.24 \mathrm{~L} \mathrm{~min}^{-1}$ 224 for TU. Water efficiency showed a broad data range from $4.2 \%$ (LR: large spray angle, high water pressure) to $49.3 \%$ (AL: small spray angle, low water pressure). Particularly for those in situ rainfall simulator studies in (semi-) arid areas with limited water availability, water consumption should be as low and used as efficiently as possible. 
Table 2

229 Main results of simulated rainfall characteristics for each rainfall simulator: water consumption, water

230 efficiency, mean Intensity [l], Christiansen Uniformity [CU], mean spatial variability (average deviation

231 from mean) of rainfall distribution, mean drop number [ $n]$, median volumetric drop diameter [ $\left.d_{50}\right]$, mean

232 kinetic energy expenditure $\left[K E_{R}\right]$, mean kinetic energy per unit area per unit depth of rainfall $[K E]$ and

233 mean momentum $[M]$.

\begin{tabular}{|c|c|c|c|c|c|c|c|c|c|c|}
\hline ID & $\begin{array}{r}\text { Water } \\
\text { consumption } \\
{\left[\mathrm{L} \mathrm{min}^{-1}\right]}\end{array}$ & $\begin{array}{r}\text { Water } \\
\text { efficiency } \\
{[\%]}\end{array}$ & {$\left[\mathrm{mm} \mathrm{h}^{-1}\right]$} & $\begin{array}{l}\mathrm{CU} \\
{[\%]}\end{array}$ & $\begin{array}{r}\text { Spatial } \\
\text { variability } \\
{[\%]}\end{array}$ & $n\left[\mathrm{~min}^{-1}\right]$ & $\begin{array}{r}d_{50} \\
{[\mathrm{~mm}]}\end{array}$ & $\begin{array}{r}K E_{R} \\
{\left[\mathrm{~J} \mathrm{~m}^{-2} \mathrm{~h}^{-1}\right]}\end{array}$ & $\begin{array}{r}K E \\
{\left[\mathrm{~J} \mathrm{~m}^{-2} \mathrm{~mm}^{-1}\right]}\end{array}$ & {$\left[\begin{array}{l}M \\
{\left[\mathrm{~kg} \mathrm{~m}^{-1}\right]}\end{array}\right.$} \\
\hline TU & 3.24 & 28.4 & 55 & 88.4 & 3.4 & 19956 & $\begin{array}{r}1.25- \\
1.75\end{array}$ & 475 & 9.88 & 0.0265 \\
\hline CO & $a$ & $a$ & 67 & 81.4 & 4.4 & 19073 & $\begin{array}{r}2.00- \\
3.00\end{array}$ & 1322 & 13.76 & 0.0459 \\
\hline BA & $a$ & $a$ & 43 & 87.0 & 8.9 & 18217 & $\begin{array}{r}1.25- \\
1.75\end{array}$ & 172 & 7.52 & 0.0132 \\
\hline GR & $a$ & $a$ & 94 & 76.4 & 10.6 & 5640 & $\begin{array}{r}4.00- \\
5.00\end{array}$ & 1149 & 8.40 & 0.0518 \\
\hline AL & 0.49 & 49.3 & 51 & 60.6 & 12.8 & 5094 & $\begin{array}{r}2.00- \\
3.00\end{array}$ & 638 & 11.51 & 0.0327 \\
\hline MA & 0.48 & 36.7 & 37 & 89.3 & 5.1 & 16671 & $\begin{array}{r}1.25- \\
1.75\end{array}$ & 252 & 7.56 & 0.0170 \\
\hline MU & 1.36 & 26.0 & 75 & 66.9 & 13.2 & 12823 & $\begin{array}{r}2.00- \\
3.00\end{array}$ & 355 & 7.78 & 0.0176 \\
\hline TR & 0.80 & 27.0 & 46 & 90.6 & 3.8 & 19695 & $\begin{array}{r}1.00- \\
1.50\end{array}$ & 214 & 5.81 & 0.0157 \\
\hline ZAC & 2.60 & 8.8 & 48 & 97.6 & 1.2 & 26797 & $\begin{array}{r}0.50- \\
1.00\end{array}$ & 77 & 3.86 & 0.0085 \\
\hline VA & 0.49 & 42.9 & 51 & 86.2 & 3.5 & 8393 & $\begin{array}{r}1.75- \\
2.50\end{array}$ & 423 & 10.84 & 0.0244 \\
\hline ZAU & 2.90 & 5.9 & 48 & 97.8 & 2.1 & 24494 & $\begin{array}{r}0.50- \\
1.00\end{array}$ & 54 & 4.16 & 0.0071 \\
\hline LR & 2.85 & 4.2 & 45 & 96.5 & 7.9 & 20725 & $\begin{array}{r}0.375- \\
0.750\end{array}$ & 25 & 0.77 & 0.0042 \\
\hline WA & $a$ & $a$ & 360 & $a$ & $a$ & 1190 & $\begin{array}{r}5.50- \\
6.50\end{array}$ & 1296 & 50.32 & 0.0917 \\
\hline
\end{tabular}

$234{ }^{a}$ Not measured

\section{Drop spectra}

237 The mean drop size and fall velocity measurements with the LPM are listed in Fig. 3. The

238 major similarity is that maximum drop numbers are attained within the two smallest drop size

239 classes $<1 \mathrm{~mm}$ (Fig. 3 and Fig. 4): in all cases, except TU and WA, >1000 drops per min

240 were only measured in those classes $<1 \mathrm{~mm}$. TU also reached 1059 drops in the drop size

241 class 1.0-1.49 mm; the drop amounts of WA are lower than 1000 drops per min for all drop

242 size classes. Amounts of drops $>1 \mathrm{~mm}$ were generally much lower than that of $<1 \mathrm{~mm}$ : $\max$.

243833 drops per min (ZAU) were measured in the drops size class $1.0-1.49 \mathrm{~mm}$ and a max. of 
244554 drops per min (AL) was detected for sizes $>1.5 \mathrm{~mm}$. The highest number of drops per $245 \min >2.0 \mathrm{~mm}$ was measured for WA (320 drops per min). More than 100 drops per min $246>3.0 \mathrm{~mm}$ were only produced by the two capillary-type simulators GR (166 drops per $\min$ ) 247 and WA (153 drops per min).

248 The data also show that the fall velocity of bigger drops is lower due to the general physical 249 restriction of low drop fall heights (Fig. 3). During all simulations, $90 \%$ or more of the 250 measured drops were slower than $3.4 \mathrm{~m} \mathrm{~s}^{-1}$. Only TU (237 drops), CO (321 drops) and GR 251 (158 drops) generated more than 100 drops per min with fall velocities $>5 \mathrm{~m} \mathrm{~s}^{-1}$. Drops $252>5.8 \mathrm{~m} \mathrm{~s}^{-1}$ were rarely measured. A few drops with velocities around $9 \mathrm{~m} \mathrm{~s}^{-1}$ were measured 253 during simulations of $\mathrm{CO}$, because the special water application unit in the simulator is able 254 to accelerate bigger drops to higher fall velocities. The velocities of smaller drops $(<1 \mathrm{~mm})$ 255 generated by the simulators were often similar to that expected for natural drops, as 256 indicated by Atlas et al. (1973) and Mätzler (2002), for vertical rainfall in calm conditions. In two 257 cases (TU and TR), more than 100 larger drops $(1.0-1.49 \mathrm{~mm})$ per min were accelerated to 258 expected natural velocities.

259 By examining single rainfall simulators, four groups can be distinguished. During the runs of 260 BA, ZAC, ZAU and LR, hardly any big drops $(>2.5 \mathrm{~mm})$ were measured. The simulators from 261 TU, MA, MU, TR and VA produced drops $>2.5 \mathrm{~mm}$, but this was much less than the capillary262 type simulators from GR and ZAU. The simulators from $C O$ and $A L$ also generated drops $263>2.5 \mathrm{~mm}$ but reached higher velocities than GR and ZAU.

264 Unfortunately, determining exact $d_{50}$ values for volumetric drop diameter was not possible 265 with the LPM for two reasons. As mentioned above, the device records only size classes and 266 not actual drop sizes, besides the fact that only drop diameters are registered. We assumed 267 a circular form of the falling drops for our calculations (Fister et al., 2011). Nevertheless, 268 calculation of $d_{50}$ values represents the best possible option for comparison with other rainfall 269 simulators (Fister et al., 2012; Hudson, 1995). Hence, the lowest $d_{50}$ value of the 13 simulators 270 was $0.375-0.750 \mathrm{~mm}$ (LR), and the highest was 5.5-6.5 mm (WA) (Table 2). 
Most studies lack accuracy concerning calculated kinetic energy of simulated rainfall (Clarke 272 and Walsh, 2007): the values are predominantly calculated from intensities only, based on the assumption that diameters and/or velocities from natural rainfall apply for simulated rainfall, too. Considering the general physical restrictions of simulated rainfall (e.g. fall height), we therefore assume, that most of the published data overestimate real values of kinetic energy. The $K E$ values calculated in this study were maximal $56 \%$ and minimal $3 \%$ of the $K E$ calculated with the three of the most commonly used equations for determining natural rainfall of equal intensities (van Dijk et al., 2002; Morgan et al., 1998; Wischmeier and Smith, 1978). Only the WA produced rainfall with a $K E$ that was greater than that calculated for natural rainfall (up to $77 \%$ more than calculated with each of the three mentioned equations). The high KE of the WA-simulator was caused by the specific characteristics (very short test duration with large, high-energy drops as described in Iserloh et al. (2013) and 283 Kamphorst (1987).

284 The calculated momentums of simulated rainfalls ranged from $0.0042 \mathrm{~kg} \mathrm{~m}^{2} \mathrm{~s}^{-1}$ for LR up to $0.0917 \mathrm{~kg} \mathrm{~m}^{2} \mathrm{~s}^{-1}$ for WA. As mentioned above, some researchers concluded that key processes of particle wash off due to rainfall are slightly more dependent on momentum than on KE (Brodie and Rosewell, 2007). Rose (1960) found that this was the case for the rate of soil detachment per unit area, and Park et al. (1980) used a momentum power relationship to predict splash erosion (Brodie and Rosewell, 2007).

290 In Fig. 4 the results of the LPM measurements were plotted in relation to the drop size 291 distribution for a hypothetical Marshall \& Palmer distribution (Marshall and Palmer, 1948) of 292 equal intensities. The box plots in Fig. 4 give additional information about the scattering of 293 drop amounts over the 25 1-min measurement intervals on five positions. A broad scattering, reflects the heterogeneity of the spatial distribution of rainfall on the respective plot, 295 described below.

296 The simulators from CO, ZAC, ZAU and LR showed little scattering in all classes, the 297 measured values were close to the Marshall \& Palmer distribution. However, in most cases 298 there were too many drops in the $0.5-0.99 \mathrm{~mm}$ drop size class and too little in the 1.0 - 
$1.49 \mathrm{~mm}$ and 1.5-1.99 $\mathrm{mm}$ drop size class. The simulators from TU, GR, MA, MU, TR and

300 VA showed higher scattering, especially in the small drop classes. The values were still close

301 to the Marshall-Palmer distribution. The results from the GR simulator were remarkable 302 because of the higher amount of drops $>3 \mathrm{~mm}$ diameter. The simulators from $\mathrm{AL}$ and $\mathrm{WA}$ 303 showed deviations from the Marshall-Palmer distribution. The AL simulator produces much 304 too less drops smaller than $0.50 \mathrm{~mm}$, whereas the WA simulator produces a relatively regular 305 drop size distribution over all classes.

\section{Spatial rainfall distribution}

308 The mean intensities based on three replicate measurements for each rain collector are 309 presented in Fig 5. Only the two simulators from Zaragoza (ZAC and ZAU) showed evenly 310 distributed intensities, caused by large spraying angles of the full cone nozzles used. All 311 other simulators showed variations over the total plot area, caused by number of applied 312 nozzles (CO) or nozzle-types as well as applied water pressure.

313 TU showed an almost uniform rainfall distribution across the whole plot (>55 $\mathrm{mm} \mathrm{h}^{-1}$, max. $31468 \mathrm{~mm} \mathrm{~h}^{-1}$ ) with only small patches of lower intensity values in the left upper corner and at 315 the outlet $\left(35-55 \mathrm{~mm} \mathrm{~h}^{-1}\right)$. The average spatial rainfall variability over the three repetitions 316 was low, in most cases between 0 and $5 \%$, only in few cases between $5 \%$ and $10 \%$ (Fig. 6 ; 317 mean values are presented in Table 2).

318 For $\mathrm{CO}$, lower rainfall intensities $\left(50-70 \mathrm{~mm} \mathrm{~h}^{-1}\right)$ were measured at the right and the left 319 edges of the plot, and at one strip in the middle. Higher intensities $\left(70-97 \mathrm{~mm} \mathrm{~h}^{-1}\right)$ occurred 320 on the upper and the lower area of the plot. Average deviations from the mean were low, and 321 almost all collectors showed values between 0 and $10 \%$. In one case, the value was between 322 $10 \%$ and $15 \%$. 


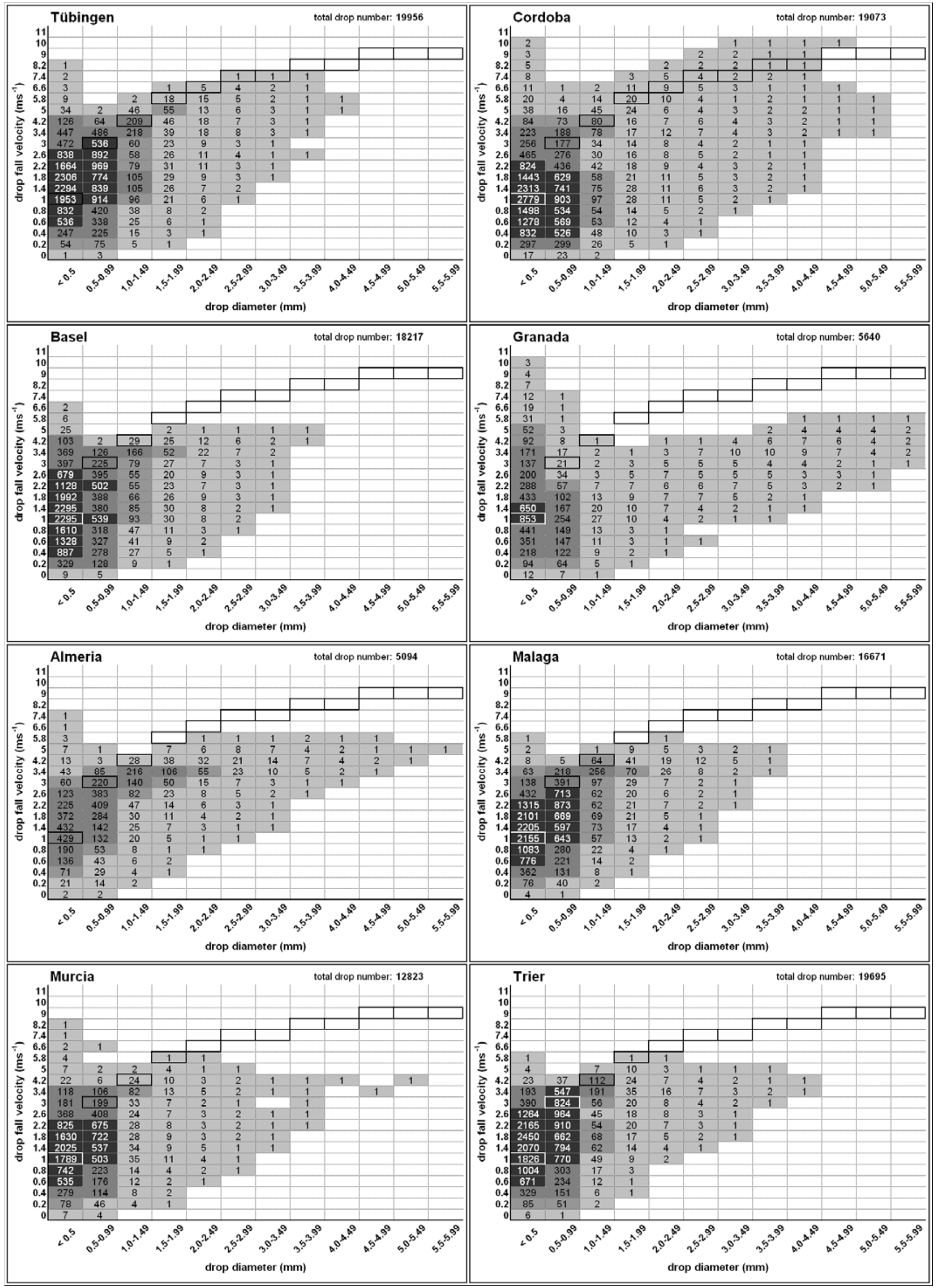



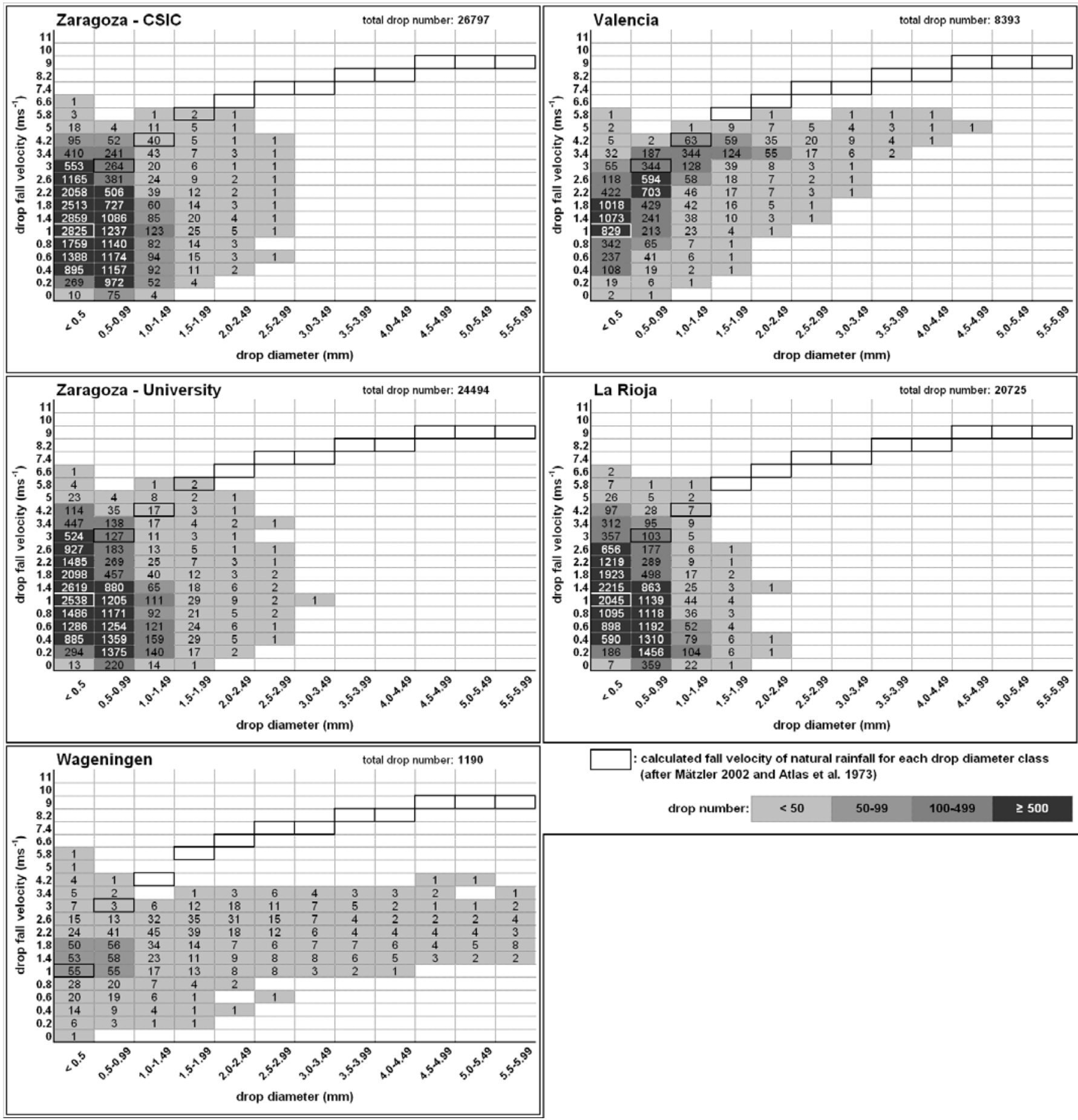

calculated fall velocity of natural rainfall for each drop diameter class (after Mätzler 2002 and Atlas et al. 1973)

\begin{tabular}{|l|l|l|l|l|} 
drop number: & $<50$ & $50-99$ & $100-499$ & $\geq 500$ \\
\hline
\end{tabular}

324 Fig. 3. Average drop size distribution and drop fall velocity for each rainfall simulator. Shown are mean

325 values representing 1 min simulated rainfall ( $n: 25$ on five positions [WA: $n: 3$ on one position]). Each

326 box gives counted total number of drops, fall velocity and drop size class. Calculated drop diameter

327 ranges and corresponding fall velocities for natural rain (Atlas et al., 1973; Mätzler, 2002) are marked

328 with a bold frame. 

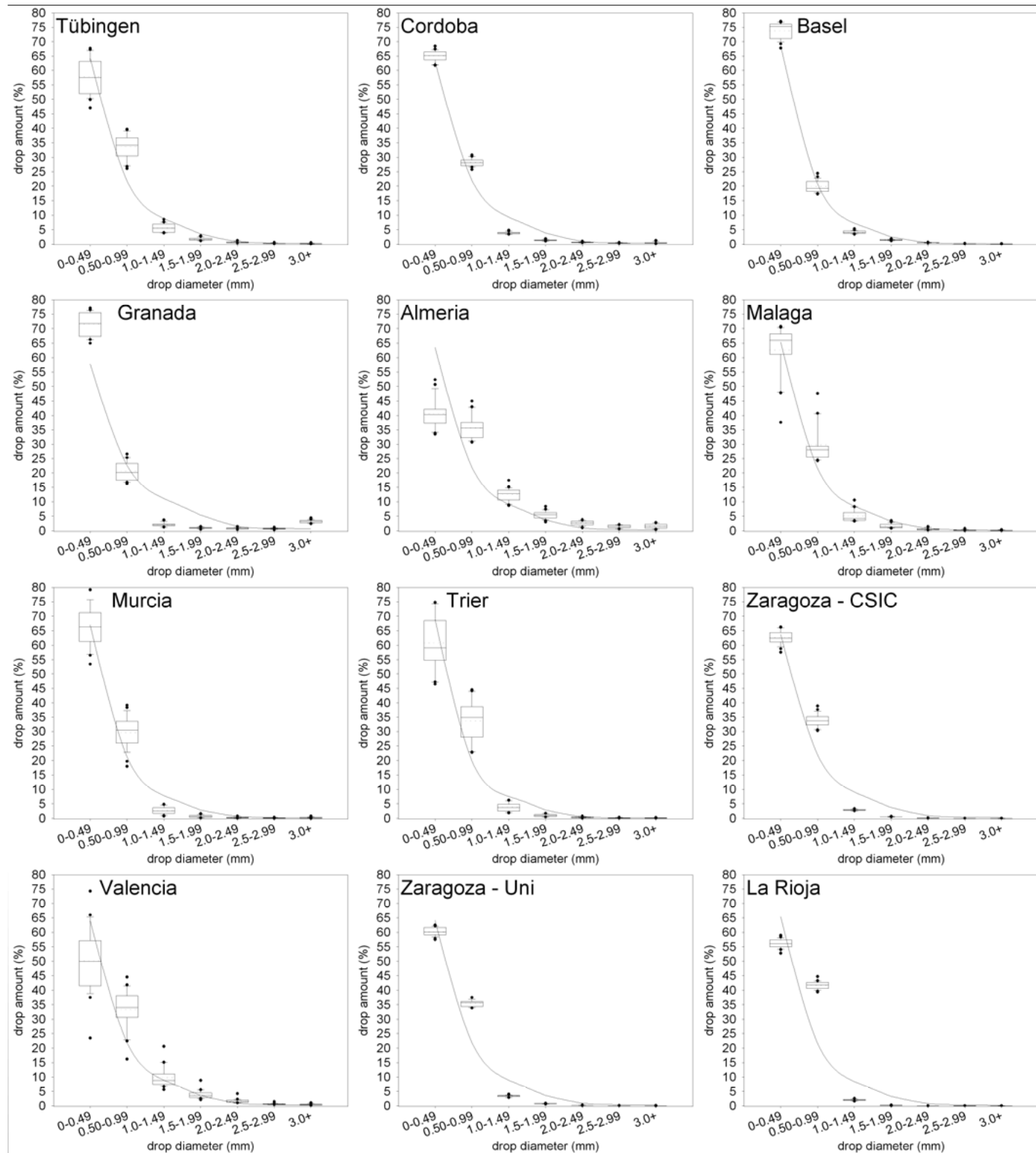

Box Plot $($ solid line $=$ median; dotted line $=$ mean $)$ Marshall-Palmer Distribution

Fig. 4. Measured drop size distributions and calculated Marshall \& Palmer distributions of equal intensities expressed as box plots for total plot ( $\mathrm{n}$ : 25 on 5 positions [WA: n: 3 on one position]). The lower and upper boundaries of each box represent the 25th and 75th percentiles, respectively, and the lower and upper error bars represent the 10th and 90th percentiles, respectively. 


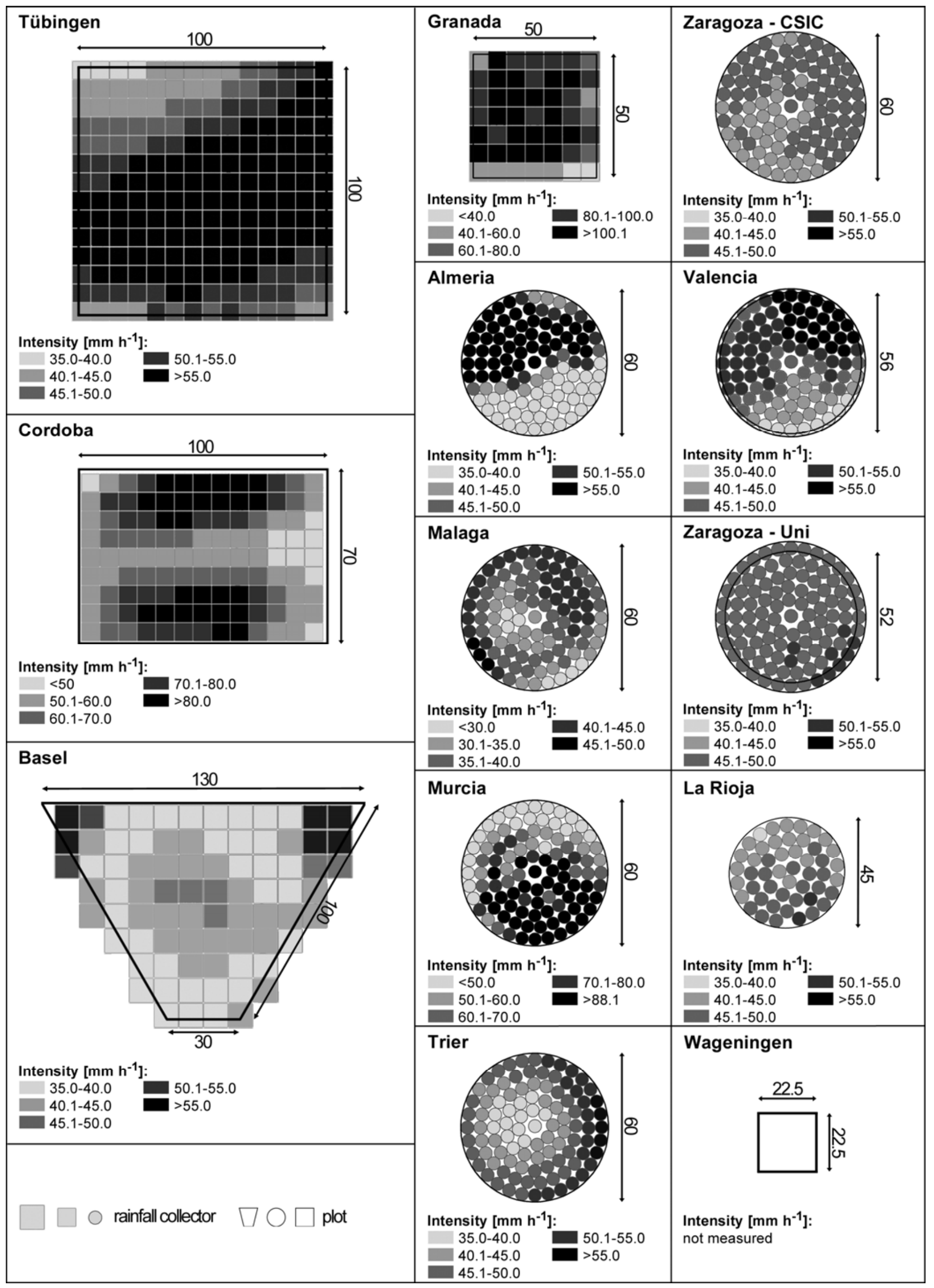

330 Fig. 5. Average spatial rainfall distributions for the rainfall simulators $\left(\mathrm{mm} \mathrm{h}^{-1} ; \mathrm{n}=3\right.$ replicates per simulator). 


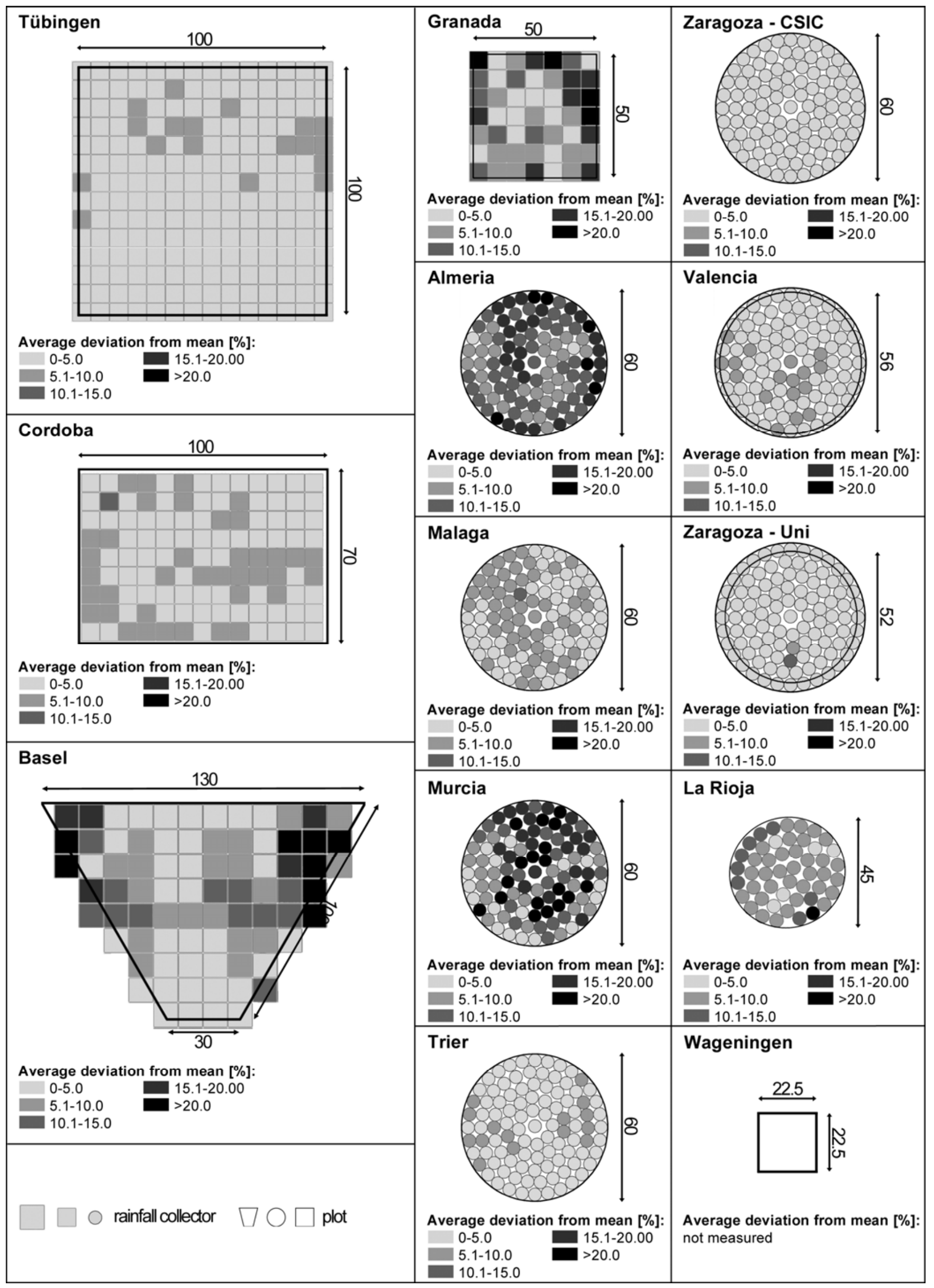

331 Fig. 6. Average spatial rainfall variability (\%) calculated from 3 replicate measurements for each simulator. 
332 The rainfall simulator from BA produced the highest intensities at the upper left and right 333 corners $\left(51-100 \mathrm{~mm} \mathrm{~h}^{-1}\right)$ and in the middle $\left(45-50 \mathrm{~mm} \mathrm{~h}^{-1}\right)$. The other collectors on the plot 334 showed values between $35 \mathrm{~mm} \mathrm{~h}^{-1}$ and $45 \mathrm{~mm} \mathrm{~h}^{-1}$. The average deviation from the mean 335 was highest at the upper left and right corners, with deviations up to $>20 \%$.

336 The intensities for GR were lowest in the first row directly at the outlet $\left(39-60 \mathrm{~mm} \mathrm{~h}^{-1}\right)$. In

337 contrast, in most of the other collectors across the plot more than twice the amounts (up to $338136 \mathrm{~mm} \mathrm{~h}^{-1}$ ) were measured. The average deviation from the mean showed an almost 339 concentric pattern of rainfall distribution. Central values ranged from 0 to $5 \%$ and increased 340 outwards, with values higher than $20 \%$ recorded around the edges.

341 The rainfall simulator from AL produced a spatial rainfall distribution with intensities below $34240 \mathrm{~mm} \mathrm{~h}^{-1}$ on the front half of the plot. In contrast, the upper half was characterized by high 343 intensities, most of them $>55 \mathrm{~mm} \mathrm{~h}^{-1}$. The average deviation from the mean was $12.8 \%$; 344 many collectors showed deviations $>10 \%$, some of them $>20 \%$.

345 The rainfall simulator from MA produced a near concentric pattern of rainfall intensity, with 346 highest intensities $\left(40-50 \mathrm{~mm} \mathrm{~h}^{-1}\right)$ recorded on the right upper area and near the left rim of 347 the plot. The other collectors showed values ranging from $28 \mathrm{~mm} \mathrm{~h}^{-1}$ to $40 \mathrm{~mm} \mathrm{~h}^{-1}$. The plot 348 was evenly covered by collectors with average deviation from the mean values $<5 \%$ and $5 \%$ 349 to $10 \%$.

350 The intensities generated by MU were higher on the front half $\left(>70 \mathrm{~mm} \mathrm{~h}^{-1}\right)$ of the plot than 351 on the upper half $\left(50-60 \mathrm{~mm} \mathrm{~h}^{-1}\right)$. The average deviation from the mean was similar to the $\mathrm{AL}$ 352 plot. Many deviations higher than $15 \%$ were recorded across the plot.

353 The TR-simulator produced a concentric pattern. Lower intensities were measured in the 354 middle (37-45 $\left.\mathrm{mm} \mathrm{h}^{-1}\right)$; the values increase outwards up to $57 \mathrm{~mm} \mathrm{~h}^{-1}$. Most of the collectors 355 showed an average deviation from the mean of less than $5 \%$, and only a few collectors 356 showed values between $5 \%$ and $10 \%$.

357 The spatial rainfall distribution of the ZAC-simulator can be separated into two parts. In the 358 lower left quarter of the plot, intensities between $40 \mathrm{~mm} \mathrm{~h}^{-1}$ and $45 \mathrm{~mm} \mathrm{~h}^{-1}$ were measured, 
359 whereas the other three quarters of the plot recorded intensities of between $45 \mathrm{~mm} \mathrm{~h}^{-1}$ and

$36050 \mathrm{~mm} \mathrm{~h}^{-1}$. The average deviation from the mean for all collectors was less than $5 \%$.

361 The intensities on the plot of the VA-simulator can be separated into three distinct areas. The 362 front area (seen from outlet) was characterized by relatively low intensities that ranged between $35 \mathrm{~mm} \mathrm{~h}^{-1}$ and $45 \mathrm{~mm} \mathrm{~h}^{-1}$. The upper right area recorded intensities up to $55 \mathrm{~mm} \mathrm{~h}^{-}$

$364{ }^{1}$, and the upper left area recorded values $>55 \mathrm{~mm} \mathrm{~h}^{-1}$. The average spatial variability over 365 the three replicates was low; and most of the collectors showed values lower than $5 \%$, with 366 only a few collectors showing values between $5 \%$ and $10 \%$.

367 The rainfall simulator from ZAU produced a very uniform intensity distribution. Almost in all of 368 the collectors, intensities between $45 \mathrm{~mm} \mathrm{~h}^{-1}$ and $50 \mathrm{~mm} \mathrm{~h}^{-1}$ were measured. Only in nine collectors, the intensity increased to values ranging between $50 \mathrm{~mm} \mathrm{~h}^{-1}$ and $55 \mathrm{~mm} \mathrm{~h}^{-1}$. With the exception of two collectors, the average deviations from the mean were less than $5 \%$.

371 The simulator used in LR produced a uniform intensity distribution. For almost all of the 372 collectors, intensities between $40 \mathrm{~mm} \mathrm{~h}^{-1}$ and $50 \mathrm{~mm} \mathrm{~h}^{-1}$ were measured. The spatial 373 variability is very heterogeneous across the plot: One collector showed an average deviation 374 from mean higher than $20 \%$, eight collectors recorded values of between $10 \%$ and $15 \%$, five collectors between 0 and $5 \%$, and all of the other collectors on the plot showed values 376 between $5 \%$ and $10 \%$.

377 Researchers argue (e.g. Esteves et al., 2000; Neff, 1979) that Christiansen Coefficients over $37880 \%$ are essential for rainfall simulation experiments. Most of the simulators meet this 379 requirement, with measured CUs ranging from $60.6 \%(A L)$ to $97.8 \%(Z A U)$. Additionally, the 380 good reproducibility of the spatial rainfall distribution (max. average deviation from mean over 381 total plot of $13.2 \%$ ) demonstrates the reproducibility of artificial rainfall of most of the simulators tested. 


\section{Conclusions}

388 The comparison of rainfall characteristics provides a good data base for improvements and a 389 consistent picture of the parameters and performance of the simulators can be quantified:

390 - The use of identical measurement methods provides a means of comparing simulated 391 rainfall characteristics of different simulators.

- The detailed database of artificial rainfall characteristics and the exact knowledge of test 393 conditions represent a prerequisite when assessing erosion, infiltration and runoff results 394 generated during field experiments.

- The LPM is used worldwide for measurements of natural rainfall. This allows detailed 396 comparisons between natural and simulated characteristics in further investigations to be 397 made.

- Kinetic energy values of the simulators are low when compared with values of natural 399 rainfall from literature. Due to the low fall height, it is not possible to reach terminal velocity 400 of large, natural raindrops (large drops are only produced when system pressure and 401 consequently spraying effect are low). This must be taken into account when field results are evaluated.

404 and parameters are well known and accurately controlled.

- Further improvements of individual simulators should concentrate on water efficiency, drop 406 size distribution, spatial rainfall distribution, as well as reproducibility, handling and control 407 of test conditions.

408 Finally, it can be concluded, that a detailed understanding about relevant features of 409 simulators as well as calibration and test procedure strategies will help to focus results and 410 knowledge, for the purpose of creating a reliable and convincing source of information. 411 Nevertheless, for practical uses, further characteristics of the simulators should be 412 considered e.g. plot size (Iserloh et al., 2013). 
The research for this study was funded by the Deutsche Forschungsgemeinschaft (DFG) project number Ri-835/6-1. We would like to thank the anonymous reviewers for their remarks.

\section{References}

Abudi, I., Carmi, G., Berliner, P., 2012. Rainfall simulator for field runoff studies. J. Hydrol. 454-455, 76-81.

Adams, J.E., Kirkham, D., Nielsen, D.R., 1957. A portable rainfall-simulator infiltrometer and physical measurements of soil in place. Soil Sci. Soc. Amer. Proc. 21, 473-477.

Alves Sobrinho, T., Gómez-Macpherson, H., Gómez, J.A., 2008. A portable integrated

Angulo-Martínez, M., Beguería, S., Navas, A., Machín, J., 2012. Splash erosion under rainfall and overland flow simulator. Soil Use Manage. 24, 163-170.

Atlas, D., Srivastava, R.C., Sekhon, R.S., 1973. Doppler radar characteristics of precipitation at vertical incidence. Rev. Geophys.11, 1-35.

Battany, M.C., Grismer, M.E., 2000. Development of a portable field rainfall simulator for use in hillside vineyard runoff and erosion studies. Hydrol. Process. 14, 1119-1129.

Birt, L., Persyn, R., Smith, P., 2007. Technical Note: Evaluation of an Indoor Nozzle-Type Rainfall Simulator. Appl. Eng. Agric. 23, 283-287.

Blanquies, J., Scharff, M., Hallock, B., 2003. The design and construction of a rainfall simulator. In: A gathering of global solutions, proceedings of the 34th annual conference (9pp.). International Erosion Control Association, 24-28 February, Las Vegas, Nevada. Available on-line at: http://www.owp.csus.edu/research/papers/papers/PP044.pdf; accessed 07.08.2012.

Bork, H.R., 1981. Oberflächenabfluss und Infiltration. Ergebnisse von Starkregensimulationen in der Südheide, Ostniedersachsen und in Südost- Spanien. Deutscher Geographentag 43, 159-163.

Boulal, H., Gómez-Macpherson, H., Gómez, J.A., Mateos, L., 2011. Effect of soil management and traffic on soil erosion in irrigated annual crops. Soil Till. Res. 115$116,62-70$.

Bowyer-Bower, T.A.S., Burt, T.P., 1989. Rainfall simulators for investigating soil response to rainfall. Soil Technol. 2, 1-16.

Brandt, C., 1989. The size distribution of throughfall drops under vegetation canopies. Catena 16, 507-524. 
Brodie, I., Rosewell, C., 2007. Theoretical relationships between rainfall intensity and kinetic energy variants associated with stormwater particle washoff. J. Hydrol. 340, 40-47.

Bryan, R., 1974. A simulated rainfall test for the prediction of soil erodibility. Z. Geomorphol. $21,138-150$.

Calvo, A., Gisbert, B., Palau, E., Romero, M., 1988. Un simulador de lluvia portátil de fácil construcción. In: M. Sala and F. Gallart (Eds.), Métodos y técnicas para la medición de procesos geomorfológicos, Sociedad Española de Geomorfología, Monografía 1, Zaragoza, pp. 6-15.

Cerdà, A., 1999. Simuladores de lluvia y su aplicación a la Geomorfología. Estado de la cuestión. Cuadernos de I. Geográfica 25, 45-84.

Cerdà, A., Ibànez, S., Calvo, A., 1997. Design and operation of a small and portable rainfall Simulator for rugged terrain. Soil Tech. 11 (2), 161-168.

Christiansen, J.E., 1942. Irrigation by Sprinkling. California Agricultural Experiment Station Bulletin 670.

Clarke, M.A., Walsh, R.P.D., 2007. A portable rainfall simulator for field assessment of splash and slopewash in remote locations. Earth Surf. Proc. Land. 32, 2052-2069.

De Ploey, J., 1981. Crusting and time-dependent rainwash mechanisms on loamy soil. In: Morgan, R.P.C. (Ed.), Soil Conservation, Problems and Prospects. Wiley, pp. 139154.

Disdromet Ltd, Basel, Switzerland, 2001. User Guide for Disdrodata V.1.22.

Esteves, M., Planchon, O., Lapetite, J.M., Silvera, N., Cadet, P., 2000. The "EMIRE" large rainfall simulator: design and field testing. Earth Surf. Proc. Land. 25 (7), 681-690

Farres, P., 1987. The dynamics of rainsplash erosion and the role of soil aggregate stability. Catena 14, 119-130.

Fernández-Gálvez, J., Barahona, E., Mingorance, M.D., 2008. Measurement of Infiltration in Small Field Plots by a Portable Rainfall Simulator: Application to Trace-Element Mobility. Water Air Soil Poll. 191, 257-264.

Fister, W., Iserloh, T., Ries, J.B., Schmidt, R.G., 2011. Comparison of rainfall characteristics of a small portable rainfall simulator and a portable wind and rainfall simulator. $Z$. Geomorphol. 55, 109-126.

Fister, W., Iserloh, T., Ries, J.B., Schmidt, R.-G., 2012. A portable wind and rainfall simulator for in situ soil erosion measurements. Catena 91, 72-84.

Fornis, R.L., Vermeulen, H.R., Nieuwenhuis, J.D., 2005. Kinetic energy-rainfall intensity relationship for Central Cebu, Philippines for soil erosion studies. J. Hydrol. 300, 2032.

Gunn, R., Kinzer, G.R., 1949. Terminal velocity of water droplets in stagnant air. Journal of Meteorol. 6, 243-248.

Hall, M., 1970. Use of the stain method in determining the drop size distribution of coarse liquid sprays. Trans. ASAE 13, 33-37. 
Hassel, J., Richter, G., 1988. Die Niederschlagsstruktur des Trierer Regensimulators. Mitteilungen der Deutschen Bodenkundlichen Gesellschaft 56, 93-96.

Hikel, H., Yair, A., Schwanghart, W., Hoffmann, U., Straehl, S., Kuhn, N.J., 2013. Experimental investigation of soil ecohydrology on rocky desert slopes in the Negev Highlands, Israel. Z. Geomorphol. Suppl. 57 (1), 39-58.

Hudson, N., 1963. Raindrop characteristics in south central United States. Rhodesian Journal of Agricultural Research 1, 6-11.

Hudson, N., 1965. The influence of rainfall on the mechanics of soil erosion. M. Sc. Thesis, University of Cape Town, Cape Town, South Africa.

Hudson, N., 1995. Soil Conservation. Batsford Ltd, London, 391 pp.

Humphry, J.B., Daniel, T.C., Edwards, D.R., Sharpley, A.N., 2002. A portable rainfall simulator for plot-scale runoff studies. Appl. Eng. Agric. 18, 199-204.

Imeson, A.C., 1977. A simple field-portable rainfall simulator for difficult terrain. Earth Surf. Processes 2, 431-436.

Iserloh, T., Fister, W., Seeger, M., Willger, H., Ries, J.B., 2012. A small portable rainfall simulator for reproducible experiments on soil erosion. Soil Till. Res. 124, 131-137.

Iserloh, T., Ries, J.B., Cerdà, A., Echeverría, M.T., Fister, W., Geißler, C., Kuhn, N.J., León, F.J., Peters, P., Schindewolf, M., Schmidt, J., Scholten, T., Seeger, M., 2013. Comparative measurements with seven rainfall simulators on uniform bare fallow land. Z. Geomorphol. Suppl. 57 (1), 11-26.

Joss, J., Waldvogel, A., 1967. Ein Spektrograph für Niederschlagstropfen mit automatischer Auswertung. Pure Appl Geophys 68, 240-246.

Kamphorst, A., 1987. A small rainfall simulator for the determination of soil erodibility. Netherlands Journal of Agricultural Science 35, 407-415.

Kincaid, D.C., Solomon, K.H., Oliphant, J.C., 1996. Drop size distributions for irrigation sprinklers. T. ASAE 39, 839-845.

King, B.A., Winward, T.W., Bjorneberg, D.L., 2010. Laser Precipitation Monitor for Measurement of Drop Size and Velocity of Moving Spray-Plate Sprinklers. Appl. Eng. Agric. 26 (2), 263-271.

Lascelles, B., Favis-Mortlock, D.T., Parsons, A.J., Guerra, A.J.T., 2000. Spatial and temporal variation in two rainfall simulators: implications for spatially explicit rainfall simulation experiments. Earth Surf. Proc. Land. 25, 709-721.

Laws, J.O., Parsons, D.A., 1943. The relation of raindrop-size to intensity. Trans. Am. Geophys. Union 24, 452-460.

León, F.J., Echeverría, M.T., Badía, D., Martí, C., Álvarez, C.J., 2013. Effectiveness of wood chips cover at reducing erosion in two contrasted burnt soils. Z. Geomorphol. Suppl. 57 (1), 27-37.

Li, X.-Y., Contreras, S., Solé-Benet, A., Cantón, Y., Domingo, F., Lázaro, R., Lin, H., Van Wesemael, B., Puigdefábregas, J., 2011. Controls of infiltration-runoff processes in Mediterranean karst rangelands in SE Spain. Catena 86, 98-109. 
Loch, R.J., Robotham, B.G., Zeller, L., Masterman, N., Orange, D.N., Bridge, B.J., Sheridan, G., Bourke, J.J., 2001. A multi-purpose rainfall simulator for field infiltration and erosion studies. Soil Res. 39, 599-610.

Luk, S., 1985. Effect of antecedent soil moisture content on rainwash erosion. Catena 12, $129-139$.

Marshall, J.S., Palmer, W.M., 1948. Relation of drop size to intensity. Journal of Meteorol. 5, 165-166.

Martínez Mena, M., Abadía, R., Castillo, V., Albaladejo Montoro, J., 2001a. Diseño experimental con lluvia simulada para el estudio de los cambios en la erosión del suelo durante la tormenta. Cuaternario y Geomorfología 15, 31-43.

Martínez-Mena, M., Castillo, V., Albaladejo, J., 2001b. Hydrological and erosional response to natural rainfall in a semi-arid area of south-east Spain. Hydrol. Process. $15,557-$ 571.

Martínez-Murillo, J.F., Ruiz-Sinoga, J.D., 2007. Seasonal changes in the hydrological and erosional response of a hillslope under dry-Mediterranean climatic conditions (Montes de Málaga, South of Spain). Geomorphology 88, 69-83.

Mätzler, C., 2002. Drop-Size Distributions and Mie Computations for Rain. Research Report No. 2002-16. Institut für Angewandte Physik, Uni Bernensis.

Medalus, 1993. Medalus II report. Silsoe College, Cranfield University, Silsoe.

Meyer, L.D., 1988. Rainfall simulators for soil conservation research. In: Lal, R., (Ed.), Soil Erosion Research Methods. Soil and Water Conservation Society, Ankeny, IO, U.S.A., 75-95.

Morgan, R.P.C., Quinton, J.N., Smith, R.E., Govers, G., Poesen, J.W.A., Auerswald, K., Chisci, G., Torri, D., Styczen, M.E., Folley, A.J.V., 1998. The European Soil Erosion Model (EUROSEM): Documentation and User Guide. Silsoe College, Cranfield University, Silsoe, Bedford.

Nadal-Romero, E., Lasanta, T., Regüés, D., Lana-Renault, N., Cerdà, A., 2011. Hydrological response and sediment production under different land cover in abandoned farmland fields in a mediterranean mountain environment. Boletín de la Asociación de Geógrafos Espanoles 55, 303-323.

Nadal-Romero, E., Regüés, D., 2009. Detachment and infiltration variations as consequence of regolith development in a Pyrenean badland system. Earth Surf. Proc. Land. 34 (6), 824-838.

Neal, J.H., 1937. The effect of the degree of slope and rainfall characteristics on runoff and soil erosion. Research Bulletin, Agricultural Experiments Station University of Missouri, Columbia, USA.

Neff, E.L., 1979. Why rainfall simulation? Proceedings of Rainfall Simulator Workshop, Tucson, Az. USDA-SEA ARM-W-10, 3-7.

Norton, L.D., 1987. Micromorphological study of surface seals developed under simulated rainfall. Geoderma 40, 127-140.

Park, S.W., Mitchell, J.K., Bubenzer, G.D., 1980. An analysis of splash erosion mechanics. In: ASAE 1980 Winter Meeting, Paper No.0-2502, p. 27. 
Poesen, J., Ingelmo Sanchez, F., Mucher, H., 1990. The hydrological response of soil surfaces to rainfall as affected by cover and position of rock fragments in the top layer. Earth Surf. Proc. Land. 15, 653-671.

Regmi, T.P., Thompson, A.L., 2000. Rainfall simulator for laboratory studies. Appl. Eng. Agric. 16, 641-652.

Regüés, D., Gallart, F., 2004. Seasonal patterns of runoff and erosion responses to simulated rainfall in a badland area in Mediterranean mountain conditions (Vallcebre, southeastern Pyrenees). Earth Surf. Proc. Land. 29, 755-767.

Ries, J.B., Iserloh, T., Seeger, M., Gabriels, D., Rainfall simulations - constraints, needs and challenges for a future use in soil erosion research. Z. Geomorphol. Suppl. 57 (1), 110.

Ries, J.B., Langer, M., 2001. Runoff generation on abandoned fields in the Central Ebro Basin. Results from rainfall simulation experiments. Cuadernos de investigación geográfica $27,61-78$.

Ries, J.B., Seeger, M., Iserloh, T., Wistorf, S., Fister, W., 2009. Calibration of simulated rainfall characteristics for the study of soil erosion on agricultural land. Soil Till. Res. 106, 109-116.

Rose, C.W., 1960. Soil detachment caused by rainfall. Soil Sci. 89, 28-35.

Roth, C.H., Meyer, B., Frede, H.-G., 1985. A portable rainfall simulator to study factors affecting runoff, infiltration and soil loss. Catena 12, 79-85.

Salles, C., Poesen, J., 1999. Performance of an optical spectro pluviometer in measuring basic rain erosivity characteristics. J. Hydrol. 218, 142-156.

Salles, C., Poesen, J., Borselli, L., 1999. Measurement of simulated drop size distribution with an optical spectro pluviometer: sample size considerations. Earth Surf. Proc. Land. 24, 545-556.

Schmidt, R.G., 1998. Beobachtung, Messung und Kartierung der Wassererosion. In: Richter, G. (Ed.), Bodenerosion - Analyse und Bilanz eines Umweltproblems. Wiss. Buchges., Darmstadt, pp. 110-121.

Scholten, T., Geißler, C., Goc, J., Kühn, P., Wiegand, C., 2011. A new splash cup to measure the kinetic energy of rainfall. J. Plant Nutr. Soil Sc. 174 (4), 596-601.

Thies, 2004. Bedienungsanleitung 021340/07/04 des Laser Niederschlags Monitor 5.4110.x0.x00 V1.09.

Torri, D., Regüés, D., Pellegrini, S., Bazzoffi, P., 1999. Within-storm soil surface dynamics and erosive effects of rainstorms. Catena 38, 131-150.

van Dijk, A.I.J.M., Bruijnzeel, L.A., Rosewell, C.J., 2002. Rainfall intensity-kinetic energy relationships: a critical literature appraisal. J. Hydrol. 261, 1-23.

Wiesner, J., 1895. Beiträge zur Kenntnis der tropischen Regens. Math. Naturwiss. Klasse Akad. Wiss. 104, 1397-1434.

Wilm, H.G., 1943. The application and measurement of artificial rainfall on types FA and $F$ infiltrometers. Trans. Am. Geophys. Union 3, 480-484. 
614 Wischmeier, W.H., Smith, D.D., 1978. Predicting rainfall erosion losses - A guide to 615 conservation planning. In: USDA Agricultural Research Service Handbook 537.

616 Zhao, Y., Hirschi, M.C., Cooke, R.A., Mitchel, J.K., Ni, B., 1996. Measurement of simulated 617 618 rainfall characteristics for raindrop erosion studies. ASAE Paper 96-2117, St. Joseph, Mich. 